\title{
Author Correction: Risk variants and polygenic architecture of disruptive behavior disorders in the context of attention-deficit/hyperactivity disorder
}

Ditte Demontis (1), Raymond K. Walters (D), Veera M. Rajagopal (1), Irwin D. Waldman (D), Jakob Grove (D), Thomas D. Als (1D, Søren Dalsgaard (1), Marta Ribasés (1), Jonas Bybjerg-Grauholm (D), Maria Bækvad-Hansen, Thomas Werge (1), Merete Nordentoft, Ole Mors, Preben Bo Mortensen \& ADHD Working Group of the Psychiatric Genomics Consortium (PGC)*, Bru Cormand, David M. Hougaard (D), Benjamin M. Neale (D), Barbara Franke (1), Stephen V. Faraone \& Anders D. Børglum (1)

Correction to: Nature Communications https://doi.org/10.1038/s41467-020-20443-2, published online 25 January 2021.

The original version of this Article contained an error in the spelling of the author Marta Ribasés, which was incorrectly given as Marta Ribasas. This has now been corrected in both the PDF and HTML versions of the Article.

Published online: 15 February 2021

Open Access This article is licensed under a Creative Commons Attribution 4.0 International License, which permits use, sharing, adaptation, distribution and ry
and indicate if changes were made. The images or other third party material in this article are included in the article's Creative Commons license, unless indicated otherwise in a credit line to the material. If material is not included in the article's Creative Commons license and your intended use is not permitted by statutory regulation or exceeds the permitted use, you will need to obtain permission directly from the copyright holder. To view a copy of this license, visit http://creativecommons.org/licenses/by/4.0/.

(c) The Author(s) 2021 